\title{
Development of Unemployment of the Roma Minority in Selected European Countries
}

\author{
A. Kajanova (Alena Kajanova)ㄱ, I. Kmecova (Iveta Kmecova)²
}

${ }^{1}$ Senior lecturer, Department of Humanistic Studies, Technical and Economic University in Ceske Budejovice, Czech Republic

${ }^{2}$ Assistant Professor, Department of Humanistic Studies, Technical and Economic University in Ceske Budejovice, Czech Republic

\section{E-mail address:}

15369@mail.vstecb.cz

\section{Reprint address:}

Alena Kajanova

Technical and Economic University in Ceske Budejovice

Okruzni 517/10

37001 Ceske Budejovice

Czech Republic

Source: Clinical Social Work and Health Intervention

Volume: 9

Issue: 4

Pages: $59-64$

Cited references: 27

\section{Reviewers:}

Pawel Czarnecki

Rector of the Warsaw Management University, Poland

Daniel J. West

University of Scranton, Department of Health Administration and Human Resources, USA

\section{Key words:}

Unemployment. Roma Minority. Post-communism. Synoptic Study.

\section{Publisher:}

International Society of Applied Preventive Medicine i-gap

CSWHI 2018; 9(4): 59 - 64; DOI 10.22359/cswhi_9_4_08 @ 2018 Clinical Social Work and Health Intervention

\section{Abstract:}

Objective: The article is aimed at analyzing the degree of unemployment of the Roma minority in selected European countries.

Design: Synoptic study.

Participants: Research data acquired from specialized databases for 1990-2018. 
Methods: Meta-analysis.

Results: The results show the lack of availability of data on the target set in most European countries, except for post-communist countries. The unemployment of the Roma minority has no relation at all to the general unemployment; it is always many times higher; it is primarily related to the exclusion of the Roma. Slight variation in the unemployment development can be seen in individual years.

Conclusion: In the first place, unemployment in segregated localities must be dealt with. This article is aimed at analyzing the degree of unemployment of the Roma minority in selected European countries. It is a meta-analysis of existing studies and reports. We used specialized databases as a source and focused on data from 1990 to 2018. For the Slovak Republic, we also found predictive data for the development of the Roma unemployment.

Studies dealing with the Roma minority are often qualitative and their results are limited to stating that the degree of Roma unemployment is higher than that of the majority population without stating any specific numbers. Additionally, many countries consider monitoring of the Roma minority as an ethnically separated group as an ethically and politically inadmissible thing. Therefore, differing data on their socio-economic situation are completely absent. If we want to deal with the unemployment of the Roma we must first allow for the fact that in most countries it is a population significantly affected by social exclusion and by related pathological phenomena. It is therefore necessary to distinguish the Roma who live in some form of segregated settlement (e.g. socially excluded localities in the Czech Republic or Slovak settlements of the Roma); from the Roma who are integrated or assimilated in the company. For example, Cada (2015) states that the unemployment in excluded localities oscillates between $80-85 \%$ even in regions where the general unemployment is below the national average. That means that the degree of Roma unemployment does not correspond with the development of the labor market in the given country. The Roma constitute one of the most endangered groups in the labor market not just because of social exclusion.

The Roma participating in the labor market often carry out works of short-term, seasonal character (Davidova et al 2010); men are involved more than women (Kajanova et al 2015). Cernusakova (2017) speaks of "invisibility" of Roma work. The reason consists in the fact that a great part of the Roma work without any employment contract, in an informal labor market; in highly unstable socially uncertain; often physically hazardous jobs.
The causes of Roma unemployment are dealt with by a number of authors. The causes include a combination of factors such as discrimination in the labor market and in public discourse in general (Gabal, Cada, Snopek 2008); decreasing number of qualified jobs (Mares, Sirovatka, Vyhlidal 2003); low education or qualification in Roma populations (O’Higgins, Ivanov 2006). Sajgalikova, Copus (2017) and Swietek (2013) and other authors see a problem primarily 
in intergenerational unemployment. If the family lacks working models the child considers such situation a standard. However, the main cause of low unemployment consists in high indebt-edness and the related wage deductions that may play a demotivating role (Trlifajova, Hurrle, Kissova 2014). Thus the Roma pass to the illegal labor market that provides fast and certain earnings. Fuzesi et al (2008) sees a cause in their bad health condition.

Hirt and Jakoubek (2006) state that the inferior position of the Roma in the labor market has many other interacting causes: additionally to the above stated, they mention insufficient motivation to work resulting from the structure of large Roma families, mutual loans, etc. One of the few studies carried out directly with employers (Stankova 2014) showed that employers consider the situation of the Roma in the labor market as unfavorable. But they see responsibility on the Roma side due to their low qualifications. In their opinion, the problem should be addressed by the government and by society, but only to a limited degree. Neumanova (2008) emphasizes the importance of supported employment, professional and pre-professional consulting within a study of the Roma population and within the employment office.
In post-communist countries, Roma employment dramatically dropped in connection with the change of the political regime when the labor market transformations affected primarily unqualified persons and members of minorities (Fuzesi et al 2008).

Table 1 below shows the degree of Roma unemployment in available data. The most data including predictive statistics were available from Slovakia. In early 21 st Century, the highest unemployment was reported from Bulgaria but it showed the strongest decrease in the course of time. On the contrary, the lowest unemployment could be seen in Hungary where it rapidly decreased as well. Slighter forms of decrease can be seen also in other countries, but with different year-on-year variations which were not caused by changes in national labor markets or by essential interventions. According to our hypotheses, they constitute methodical distortions. Variations in the results of individual studies can be seen for example in Slovakia where the outputs of different authors for the same year sometimes differ by more than $15 \%$. We also consider it interesting that Romania that has the highest percentage of Roma population shows a considerably lower percentage of unemployed Roma than other analyzed countries.

Table 1: Degree of Roma unemployment in selected countries and its development in the course of time

\begin{tabular}{|l|l|l|l|}
\hline Year & Country & $\begin{array}{l}\text { Degree of Roma } \\
\text { Unemployment }\end{array}$ & Source \\
\hline 2000 & Czech Republic & $46.3 \%$ & (Sirovatka 2003) \\
\hline 2005 & Czech Republic & $70.0 \% *$ & (Malan, Shreedhar 2007) \\
\hline 2008 & Czech Republic & $11.7 \%$ & (Czech Government 2009) \\
\hline 2011 & Czech Republic & $39.0 \%$ & (Czech Government 2012) \\
\hline 1997 & Slovakia & $78.0 \% *$ & (OECD 2004) \\
\hline 2000 & Slovakia & $84.8 \% *$ & (Sirovatka 2003) \\
\hline $2000-2005$ & Slovakia & $78.2 \% *$ & (Marcincin, Marcincinova 2009) \\
\hline 2002 & Slovakia & $83.0 \% *$ & (OECD 2004) \\
\hline 2004 & Slovakia & $67.0 \% *$ & (Hidas et al 2018) \\
\hline
\end{tabular}




\begin{tabular}{|l|l|l|l|}
\hline 2005 & Slovakia & $73.1 \%{ }^{*}$ & (Filadelfiova, Gerbery 2012) \\
\hline $2006-2010$ & Slovakia & $65.4 \%^{*}$ & (Marcincin, Marcincinova 2009) \\
\hline 2011 & Slovakia & $70.0 \%^{*}$ & (Messing 2014) \\
\hline $2011-2015$ & Slovakia & $62.6 \%^{*}$ & (Marcincin, Marcincinova 2009) \\
\hline 2012 & Slovakia & $73.0 \% *$ & (Stefancova 2014) \\
\hline 2016 & Slovakia & $55.0 \% *$ & (Hidas et al 2018) \\
\hline $2016-2020$ & Slovakia & $62.6 \%^{*}$ & (Marcincin, Marcincinova 2009) \\
\hline 2017 & Slovakia & $41.0 \% *$ & (Hidas et al 2018) \\
\hline 2000 & Hungary & $56.5 \% *$ & (Sirovatka 2003) \\
\hline 2011 & Hungary & $50.0 \% *$ & (Messing 2014) \\
\hline 2015 & Hungary & $28.3 \% *$ & (KamaraOnline 2016) \\
\hline 2000 & Bulgaria & $80.0 \% *$ & (Sirovatka 2003) \\
\hline 2010 & Bulgaria & $59.0 \% *$ & (Flanagin 2014) \\
\hline 2011 & Bulgaria & $40.0 \% *$ & (Messing 2014) \\
\hline 2000 & Romania & $76.9 \%^{*}$ & (Sirovatka 2003) \\
\hline 2010 & Romania & $50.0 \% *$ & (Flanagin 2014) \\
\hline 2011 & Romania & $33.0 \% *$ & (Messing 2014) \\
\hline 2011 & Romania & $51.0 \% *$ & (Ionescu, Banu 2015) \\
\hline 2012 & Poland & $90 \% *$ & (Swietek 2013) \\
\hline
\end{tabular}

* Roma population aged 15-64 years from segregated localities

\section{Conclusion}

The results of our analysis show that primarily the unemployment in segregated localities must be urgently addressed. In other cases, Roma unemployment is higher than that of the non-Roma population, but the difference is not so sharp. The main causes of unemployment of the minority seem to consist primarily in social exclusion, not in ethnicity as such. A unified methodology for measuring of the degree of unemployment would contribute to deeper understanding of the issue in question.

\section{Acknowledgment}

The work presented in this paper has been supported by the project Nr. 2018/8110/005 „Specific Approaches to Roma Employees“ Internal grant competition of The Institute of Technology and Business in Ceske Budejovice.

\section{References}

1. CADA K et al (2015) Analysis of socially excluded localities in the Czech Republic. Prague: GAC, s.r.o.

2. CERNUSAKOVA B (2017) Roma: The Invisible Workforce of Ostrava. Race and Class Vol. 58 No. 4 2000, pp. 98-105, https://doi. org/10.1177/0306396816686275.

3. DAVIDOVA E et al (2010) Quality of life and social determinants of health among Roma in the Czech and Slovak Republics. Prague: Triton. ISBN 978-80-7387-428-5.

4. FILADELFIOVA J, GERBERY D (2012) Report on living conditions of Roma households in Slovakia. Bratislava: UNDP. ISBN 978-80-89263-10-3.

5. FLANAGIN J (2014) The Roma may be just what Europe needs to recover. In Quartz [online]. 31.10.2014 [cit. 2018-10-12]. Available from: https://qz.com/280695/theroma-may-be-just-what-europe-needs-torecover/. 
6. FUZESI Z, BUSA C, VARGA I, TISTYAN L (2008) Employment Discrimination in Hungary and Its Effect on Health. NEW SOLUTION: A Journal of Environmental and Occupational Health Policy Vol. 18 No. 4 2008, pp. 415-440. ISSN 1048-2911.

7. GABAL I, CADA K, SNOPEK J (2008) The key to strengthening the integration policy of municipalities: social exclusion of Roma and Czech society. Prague: Open society o.p.s. ISBN 978-80-87110-07-2.

8. HIDAS S, LAFFERSOVA Z, MACHLICA $\mathrm{G}$ (2018) The inclusion of the Roma is an all-society challenge [online]. Ministry of Finance of the Slovak Republic Financial Policy Institute [cit. 2018-10-12]. Available from : http://www.mfsr.sk/Default.aspx?Cat $\mathrm{ID}=11824$

9. HIRT T, JAKOUBEK M (2006) Roma in settlements of social exclusion. Pilsen: Publishing And Publishing House Ales Cenek. ISBN 80-86898-76-8.

10. IONESCU I, BANU O (2015) STATE OF EMPLOYMENT AMONG THE ROMA PEOPLE 1. Journal of Community Positive Practices Vol. 15 No. 4 2015, pp. 73. ISSN 1582-8344.

11. KAJANOVA A et al (2015) (No) equality in Roma families. Prague: People's Newspaper. ISBN 978-80-7422-455-3.

12. MALAN M, SHREEDHAR J (2007) Czech Republic: Time Bomb for Roma [online]. Transition online [cit. 2018-10-11]. Available from: http://www.tol.org/client/article/18752-time-bomb- for-roma.html.

13. MARCINCIN A, MARCINCINOVA L (2009) Losses from exclusion of Roma. The key to integration is respect of differences [online]. Available from: https://www. iz.sk/download-files/sk/osf-straty-z-vylucenia-romov.pdf [cit. 2018-10-12].

14. MARES P, SIROVATKA T, VYHLIDAL J (2003) Long-term unemployed-life situations and strategies. Sociological Magazine Czech Sociological Review Vol. 39, No. 1 2003, pp. 37-54.
15. MESSING V (2014) Patterns of Roma Employment in Europe. NEUJOBS Policy Brief [online]. Budapest: Center of Policy Studies, Central European University [cit.2018-10-12]. Available from: http:// www.neujobs.eu/sites/default/files/publication/2014/04/D19.4_policybrief_review\%20(1).pdf

16. NEUMANOVA L (2008) The importance of supported employment for people with socio-cultural disadvantage, with Roma nationality [online]. Brno [cit. 2018-0620]. Available from: <https://is.muni.cz/th/ diqhp/>. Diploma thesis. Masaryk University, Faculty of Education.

17. OECD Economic Surveys: Slovak Republic. Paris: OECD Publishing, 2004/1. ISSN 0376-6438.

18. O`HIGGINS N, IVANOV A (2006) Education and employment opportunities for the Roma. Comparative Economic Studies Vol. 48 No. 1 2006, pp. 6-19.

19. SAJGALIKOVA H, COPUS L (2017) Can employers and educational institutions learn more about their candidates through analyzing their heroes .Proceedings of the 30th International Business Information Management Association Conference, IBIMA 2017 - Vision 2020: Sustainable Economic development, Innovation Management and Global Growth, pp. 3937-3944.

20. SIROVATKA T (2003) Exclusion of Roma in the labor market and chances for their inclusion [online] Social Studies 10, 2003 [cit. 2018-10-11]. Available from: https:// anzdoc.com/exkluze-rom-na-trhu-prace-aance-na-jejich-inkluzi-.htm.

21. STANKOVA M (2014) Gypsies on the labor market from an employer perspective [online]. Brno [cit. 2018-06-20]. Available from: <https://is.muni.cz/th/km5af/>. Diploma thesis. Masaryk University, Faculty of Social Studies.

22. STEFANCOVA V (2014) Employment of Roma as an indicator of the current state of equal opportunities in the labor 
market of the Slovak Republic [online]. Trencin: Trencin University of Alexandra Dubceka [cit. 2018-10-12]. Available from: https://www.academia.edu/7272876/ ZAMESTNANOST_ROMOV_AKO_INDIKATOR_SICASNEHO_STAVU_ROVNOSTI_PRILEZITOSTI_NA_TRHU_ PRACE_SLOVENSKEJ_REPUBLIKY.

23. SWIETEK A (2013) Education of the Roma ethnic minority in Poland on the background of social and economic conditions. Czasopismo Geograficzne Vol. 84 No. 1-2 2013, pp. 65-81.

24. TRLIFAJOVA L, KISSOVA B, HURRLE $\mathrm{J}$ (2014) When the work pays off. Analysis of economical motivations to employment. Prague: MKC Prague, ops.

25. Report on the state of the Roma minority in the Czech Republic in 2011. Government of the Czech Republic [online], 2012 [cit.
2018-10-11]. Available from: https://www. vlada.cz/cz/ppov/zalezitosti-romske-komunity/aktuality/zprava-o-stavu-romske-mensiny-v-cr-za-rok-2011-100979/

26. Report on the Situation of Roma Communities in the Czech Republic in 2008. Government of the Czech Republic [online], 2009 [cit. 2018-10-11]. Available from: https://www.vlada.cz/cz/ppov/zalezitosti-romske-komunity/dokumenty/zprava-ostavu-romskych-komunit-v-ceske-republice-za-rok-2008-63158/

27. Roma in the Hungarian labor market: a comprehensive view of the CSO. KamaraOnline-News, Business Information, Analyzes, Business and Applications, Downloadable Document Sheets [online]. 28.10.2016 [cit. 2018-10-12]. Available from http://kamaraonline.hu/cikk/a-romak-a-magyar-munkaeropiacon-atfogo-kep-a-ksh-tol 